\title{
Tror alle, men tviler på alt
}

\author{
Om leger kan man tenke at de er gartnere i andres eksistens. Kjell Johansen var lege for \\ leger og forundrer seg over hvor sårbare vi er. At «omsorg og tenking er sjelens gymnastikk» \\ har han fra kollega Hippokrates. Og aller best lyder det på latin: «Cura et cogitatio animi \\ exercitatio est.»
}

Når man er ung, ser man etter trygge voksne som viser interesse og møter blikket. Som førsteårs medisinstudent i 1977 møtte jeg Kjell Johansen. Han var lege ved Institutt for almenmedisin i Bergen, kollega og venn av min far. De var unge ivrige menn, jeg husker latter og hvite frakker, luktene av legekontor og venterom, moderlige sykepleiere som lot meg ta min første famlende venøse blodprøve i en raus arm. Og jeg husker Kjell som entusiastisk tok meg med på skadestuen der en blek tømrer hadde fătt tommelen halvt kuttet av. Det var skummelt og kvalmende og umulig å se for seg som noe jeg selv en gang skulle kunne håndtere. «Man venner seg til det og da blir det gøy,» sa Kjell Johansen så overbevisende at jeg nesten trodde ham.

Nær 40 år senere oppsøker jeg den samme mannen. Jeg vil finne ut hvem han er og har vært. Han har levd i 75 år, jeg vet litt om livet hans, men har mange spørsmål. Hva skjedde med de akademiske ambisjonene? Hva slags tanker sitter han med etter å ha hjulpet mennesker i sykdom og krise gjennom 40 år? Han var den første offisielle lege for leger i Hordaland fylke, en skriftefar for kolleger i krise. Hva lærte han av det? Er det noe vi trenger å vite?

Vi møtes på restaurant i Bergen sentrum. Regnet drysser over Fløibanestasjonen. Kjell Johansen smetter over våt brostein, kortklippet grå under paraplyen. Vi går til bords og byr opp til samtale, ledsaget av kortreist sei, lyr, hjort og epler fra Vestlandet. Dråpene kommer fra fjernere strøk, slik de har gjort i tusen år her hvor Norges vikingkonger holdt hoff.

\section{Naiv og dumsnill?}

- At jeg som lege alltid skal trøste, det har jeg hatt med meg hele tiden.

- Helt fra starten?

$$
-\mathrm{Ja} \text {. }
$$

- Men lærte du å trøste på studiet, det gjorde ikke vi?

- Nei, men det var helt naturlig for meg å gjøre det. Jeg hadde et langt sykehusopphold da jeg var 18 år. Jeg erfarte hvordan plager og uvisshet ble lettere å bære når vi fikk omsorg.

- Ble du ikke blindet av legestudiet der alt som var interessant handlet om diagnosene, ikke livet til personen som var syk?

Han smiler.

\section{«Jeg gjorde det til et mål å oppføre meg slik at det skulle være enkelt å komme etter meg»}

- Nei, iallfall ble jeg ikke blind på begge øynene.

- Og du ble ikke sint på pasienter som «ikke feilte noe»?

- Nei aldri. Derimot ble jeg sint når jeg så kolleger som oppførte seg hensynsløst mot medarbeidere med lavere rang. Som forlot et undersøkelsesrom i kaos uten å tenke på dem som kom etter og måtte rydde opp. Jeg gjorde det til et mål å oppføre meg slik at det skulle være enkelt å komme etter meg.

- Du er snill? Ikke aggressiv?

- Nei det skal mye til.

- Du er godtroende?

- Ja, naiv og dumsnill.

- Hvordan vet du det?

- Jeg har latt folk utnytte meg og skjønt det i ettertid. Jeg burde nok blitt sint iblant, men jeg føyet meg - mer enn jeg liker å tenke på. Jeg er utvilsomt konfliktsky.
Trøster meg halvhjertet med Thorvald Stoltenberg som har sagt at det er slike vi trenger, hva skal vi med flere konflikter? Men noen ganger må man skrike ut, våge å si ifra. Det våget ikke alltid jeg.

\section{Arven}

- Det er nok en del av min sosiale ballast dette med å være føyelig. Både far og farfar var sjøfolk som sjelden laget bråk. Husk at vi var vanlige småkårsfolk i en liten kystbygd på Fosen.

Kjell løfter blikket og ser strengt på meg: - Men vi led aldri nød, det skal du vite! Så mildner han igjen. - Vi tok det som en selvfølge at andre bestemte. Vi kjente vår plass: et skritt bak dem som hadde utdanning og penger, som lensmann, lærer, prest, handelsmann og distriktslege. De var fjerne skikkelser, men de fantes og de innebar at vi «vanlige» så oss selv som mindre viktige. Jeg tror aldri jeg helt kan riste av meg den holdningen.

- Hadde dere bokhyller hjemme?

- Ja, det hadde vi. Men en grunn til ikke å kjøpe bøker var at de samlet så mye støv. Da jeg var ti år, kom en kolportør rundt på dørene. Da kjøpte mamma to bøker, jeg har dem ennå: Tarzan, apenes konge og Fars gutt. De åpnet en ny verden. Så fant jeg skolebiblioteket. Siden har jeg vært en bokorm. Lesing er mitt tilfluktssted, bøkene er vel i realiteten min nærmeste vennekrets nå $\mathrm{i}$ alderdommen.

- Du må forstå hvor langt fra det urbane vi levde den gangen i 1940-årene. Jeg hadde bare en søster, hun var yngre enn meg. Under krigen fikk hun difteri. Hun ble svært dårlig, fikk nesten ikke puste, svelget var fylt av membraner. Legen la henne inn for øyeblikkelig hjelp. Kjells øyne fylles plutselig av tårer:

- Øyeblikkelig hjelp, Edvin. Det tok 18 timer med båt til Trondheim! Hun var nesten død da hun kom frem og ble trakeostomert. 


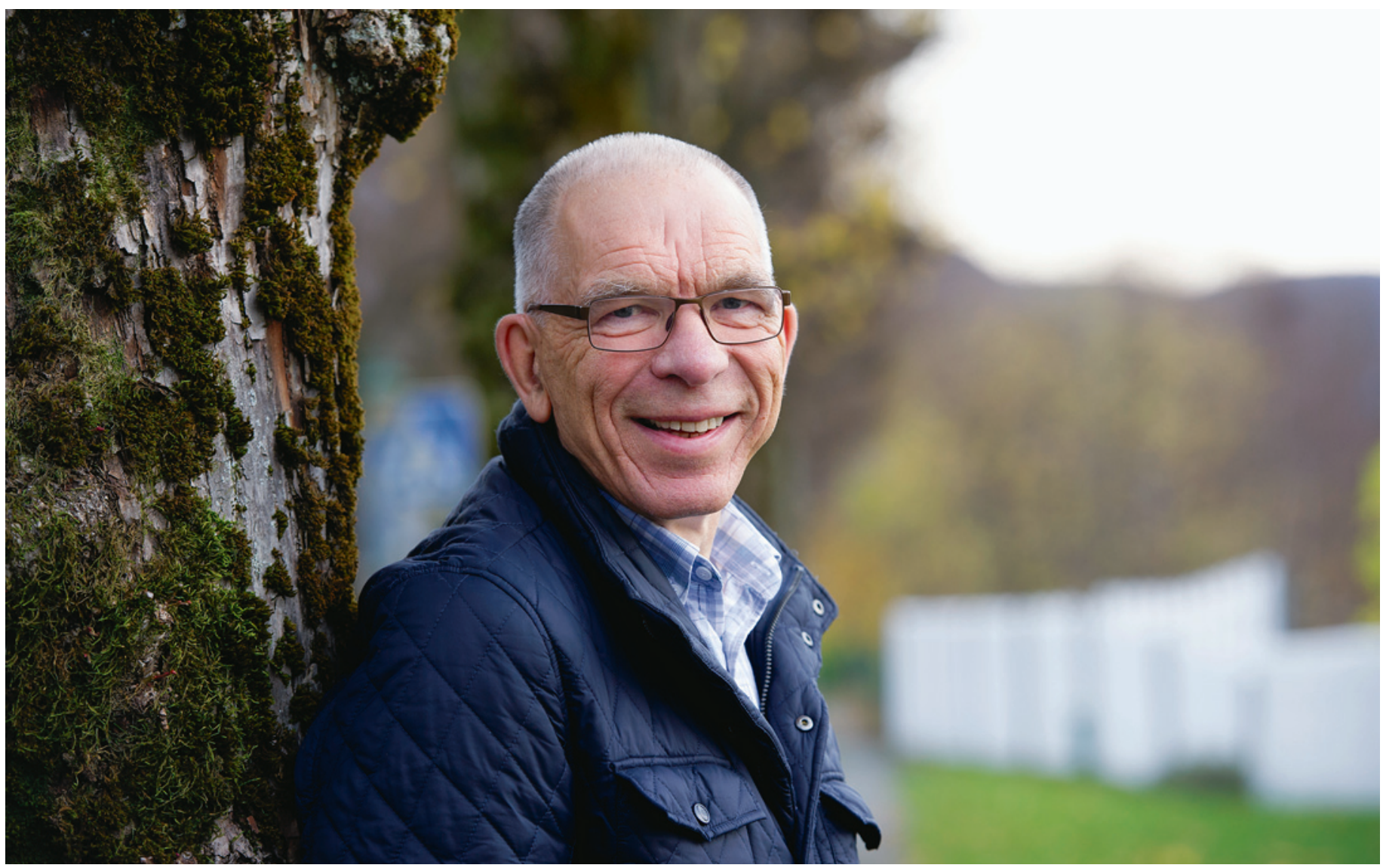

Foto: NTB scanpix

\section{Kjell Johansen}

Født 1939 i Jøssund kommune,

Sør-Trøndelag

- Cand.med. Bergen 1966, distriktslege i Fusa 1968-71

- Privatpraksis og i perioder stipendiat ved Institutt for almenmedisin, Bergen 1972-85

- Allmennpraksis i Bergen 1985-2006

- Formann i komiteen for Solstrandkurset 1975-80

- Formann i kurskomiteen i Hordaland lægeforening 1981-89

- Første leder av ordningen Lege for leger i Hordaland, fra 1990

\section{Indre asyl}

- Din far var lite hjemme da du var gutt. Ble du kjent med ham?

- Vi hadde fin kontakt etter at familien flyttet til Trondheim da jeg var 12 år. Men vi snakket ikke om livets store spørsmål. Heller ikke i voksne år fant jeg fortrolige. Jeg har forsøkt, men opplevde at ingen kunne eller ville følge meg til bunns i det jeg var opptatt av. Så jeg ga meg. Selv om det var mer igjen å lette seg for, mer igjen å forstå. Jeg skjønte at «det er nok nå». Den som kjenner meg best, er kona mi. Hun er en god samtalepartner.

- Når skjønte du at du var interessert i dybde?

- Etter hvert som jeg møtte mennesker. Og jeg har jo ikke gjort annet.

- Det er en ensomhet i det du sier nå. Et indre asyl.

- Asylum betyr fristed. Det går an å ha det slik.

- Du betaler en pris?

- Jeg har vent meg til å tenke at jeg må bruke det jeg har. Har lært av de alvorlig syke. Når kreften herjer, når hjerte og nyrer er elendige, så finnes det allikevel en livsbejaelse der. Og som lege gjelder det å gi kraft til det som finnes, være med på å peke det ut. Det har jeg brukt på meg selv også.
- Jeg trodde du var utadvendt?

- Livets kilevinker har gjort meg vár. Jeg er et du-menneske, men lever tilbaketrukket.

- Ryktene sier at Kjell Johansen har vært et avgjørende terapeutisk «du» for mange pasienter, en særlig kompetent doktor og veileder. Kan det stemme?

- Det jeg står for og tenker, det er vel greit nok.

- Det faller deg ikke spesielt lett å si noe som kunne fremheve deg selv, merker jeg.

Jeg spidder Kjell med blikket for å se om han lar seg utfordre. Han humrer og vender oppmerksomheten mot kniv og gaffel.

- Vil du ha mer vin?

- Ja, men bare en liten smak. Jeg passer på å være intakt i hodet, man vet aldri når man får bruk for det. Skål!

\section{Turberkuløs meningitt}

- Det var tuberkulosen som gjorde at jeg ble lege. Jeg ble innlagt i 1957, knapt 18 år gammel, med tuberkuløs meningitt. Ubehandlet er den $100 \%$ dødelig. Men det visste ikke jeg. Jeg var nok smittet av min mor, hun lå på sanatorium i 1940-årene. Hun overlevde og ble frisk. Så fikk jeg det. Jeg ble omtåket, legen forsto ikke hva det var. Jeg var ikke nakkestiv, men myk som 
en katt. Jeg ble liggende fem måneder på sykehuset og mistet et klassetrinn. Jeg fikk $\mathrm{i}$ alt $40 \mathrm{~g}$ streptomycin. Det var ny medisin da, og den reddet livet mitt. Etterpå måtte jeg gå med hatt og ikke røre en fotball det første året, det var forferdelig. Jeg fikk nye tanker i hodet der på sykehuset, det var så mye som var ukjent og interessant. Tenkte at hvis jeg fikk gode nok karakterer så skulle jeg søke på medisin. Og slik ble det.

- Jeg var god i matte den gangen, en hardbarket realist. Men så ble jeg en slags filosof med årene. Det snek seg inn gjennom arbeidet. De store spørsmålene i de små hendelsene: Hva gjør man med all usikkerheten, uvitenheten, ubestemtheten i medisinske beslutninger? Hva er bra for dette mennesket som ber om hjelp? Og hva med meg selv, hva lengter jeg etter? Jeg leser Martin Buber for tiden, Jeg og $d u$, halvt filosofi og halvt poetisk mystisisme. Den er ikke lett, men det gir gjenklang. Jeg leter nok etter et system som tanken kan hvile i.

\section{Å bygge et fag}

Kjell Johansen var en av fire unge leger som i 1972 ble headhuntet til nyopprettede Institutt for almenmedisin ved Universitetet i Bergen, med en gruppepraksis som skulle tjene som «utstillingsvindu» for studenter og interesserte leger. Instituttets mål var å løfte det faglige nivået i norsk allmennmedisin, som hadde forfalt $i$ etterkrigstiden. Kjell var ung distriktslege i Fusa da han ble oppringt av Bergens første professor i allmennmedisin, Sigurd Humerfelt.

- Jeg sa straks ja. Jeg visste jo at det var behov for kunnskap og fagutvikling i allmennmedisinen. Da jeg begynte i Fusa, sendte vi blodprøvene i vanlig post til Haukeland. De humpet av gårde med postbilen i kulde og varme, om vinteren frøs nok rørene, og svarene vi fikk var saktens underlige iblant. Men man ville jo ikke tro at blodprøvesvar kunne være misvisende! Ingen hadde hørt om preanalytiske feilkilder. Tall er forførerisk tillitvekkende, det har ikke endret seg. Den erfaringen gjorde at jeg laget laboratoriekurs på instituttet.

- Du er en slik type som ikke bare klager på ting som er feil, du gjør noe med dem?

- Dyd av nødvendighet, kan det vel kalles. Jeg skulle vikariere for distriktslegen, mutters alene. Scenarioet jeg fryktet mest var «kvinne i fertil alder med vondt i magen, bor langt unna». Jeg var helt blank på det som het barnsnød. Derfor tok jeg familien med til Sverige et halvt år, der jeg jobbet på fødeavdeling, før vi kom tilbake til Fusa. Det ble noen forløsninger, og det var usigelig godt å kjenne at man hadde en trygghet i den situasjonen. Jeg hadde til og med tang, som jeg heldigvis slapp å legge. Så laget jeg mitt eget skjema for å følge opp de gravide på en systematisk måte. Da jeg kom til Bergen, skjønte jeg at flere hadde laget slike skjemaer. Jeg ble med i et utvalg under Sosialdepartementet, og vi laget NOU 1984: 17 Perinatal omsorg $i$ Norge, og utviklet opphavet til helsekortet for gravide, som fortsatt brukes.

- I de 14 årene jeg jobbet på Institutt for almenmedisin var det særlig videre- og etterutdanning som fenget meg. Jeg var med i fagutvalget i Alment praktiserende lægers forening (Aplf) og jobbet med Solstrandkurset. Det ble en nytenkingsarena. Jeg tror vi la ned noen grunnsteiner som faget fortsatt står på. Allmennmedisinen trengte goodwill, penger og ressurspersoner. Vi hentet inn de største kanonene fra Europa, legender som John Fry fra England og Frans Huygen fra Nederland $(1,2)$. Det var utrolig spennende, jeg husker jeg var både skjelven og svett da jeg sto på Flesland og ventet på dem. Og jeg frydet meg over å finne en felles menneskelig bølgelengde, som gode kolleger.

\section{Lege for leger}

- Du ledet ordningen Lege for leger fra starten i 1990. Var det annerledes enn å være lege for andre folk?

- Ja og nei. Det kom professorer og kjente leger. I starten kunne jeg bli redd for kunnskapen deres, ville skygge unna. Men de var engstelige som folk flest, hadde gjerne lite kunnskap om seg selv og sine kropper rent klinisk, og ofte forunderlig lite selvinnsikt. Jeg har lurt på om det er et uttrykk for spesialisering i faget? Eller at studiet aldri har gitt unge mennesker hjelp til å forstå hva som er viktig?

Da Kjell Johansen pensjonerte seg, hadde han mange leger på pasientlisten. En av dem forteller: «Kjell hjalp meg gjennom mine foreldres skilsmisse, så min egen. Han inviterte oss til felleskonsultasjoner. Prøvde ikke å reparere forholdet, men hjalp oss til å høre hverandre slik at vi klarte å samarbeide. Jeg var veldig imponert da. Han sa lite, men hadde enorm ro og et trygt blikk, man kunne gå rett til kjernen i saken. Jeg følte aldri at vi hadde tidspress. Skjønner ikke hvordan han klarte det. Kanskje er slik legekunst ikke noe alle ønsker, det kan virke for nærgående. Men for meg var det livsviktig.»

- Er terapeutisk lytting en nådegave eller noe leger kan lære, Kjell?

- Lytting er en medisinsk kjerneferdighet og kan selvsagt læres. Men det er vanskeligere enn det meste. Jeg øvde meg i alle år. Âpningen av samtalen er viktig: Når jeg har hilst, vender jeg meg mot personen uten å si stort, lar pasienten gå opp det første sporet. Så hører jeg nysgjerrig på det som sies og ikke sies, og undrer meg. Fortellin- gene kan bli lange og detaljerte, men de må fremføres i alle fall én gang. Så må opplysningene vurderes og suppleres gjennom klinisk arbeid. Jeg laget meg et ordtak av det: «Jeg tror alle, men tviler på alt.» Det har mer schwung på latin: Hominibus credo omnibus de omnibus dubito rebus.

Kjell smiler fornøyd.

\section{Det oppreiste sinn}

Mange studenter og kolleger ble i årenes løp invitert inn på Kjells legekontor som gjester og samtalepartnere. Noen utvalgte fikk med seg en vakker loddsnor i sølv, spesiallaget etter Kjells design. De fikk også sitatet som lå bak, fra Johan Falkbergets roman An-Magritt: «Det oppreiste sinn står i loddsnorens tegn.»

Men den største inspiratoren ble Olav H. Hauge, gartneren fra Ulvik. Kjell var kursleder og inviterte Hauge til å lese dikt på Solstrandkurset i 1975. Det ble et sterkt møte med den beskjedne, men åpne mannen Hauge skrev i dagboken: «Attende frå Bergen. Las dikt på Solstrand i Os, der praktiserende legers forening hadde seminar. Sigbjørn Osa spela. Bodil møtte meg på stasjonen då eg kom. - Gjekk bra på Solstrand» (3).

Kjell rekker meg en konvolutt. Den inneholder et forseggjort takkekort i svart-hvitt, med diktet Gjer ein annan mann ei beine (beine $=$ tjeneste) trykt på innsiden, underskrevet med Olav H. Hauges dirrende gammelmannssignatur. Kjell smiler:

- Han ga meg sin personlige tillatelse til å bruke diktet. Det er en god rettesnor for en lege:

Han kom or fjellet, skulde heim,

fekk føring ifrå Osa

ut til Øyvindstò.

Og han var raust

og baud betal.

Men Osamannen

var ikkje fal.

Eg vil betala;

eg kan ikkje nå deg

med ei beine att.

Så gjer ein annan mann

ei beine då,

sa Osamannen,

og skauv ifrå.

\section{Edvin Schei}

edvin.schei@igs.uib.no

Universitetet i Bergen

\section{Litteratur}

1. Huygen FJA. Family medicine. The medical history of families. Nijmegen: Dekker \& van de Vegt, 1978. Blythe M. Almost a legend - John Fry, leading reformer of general practice. London: The Royal Society of Medicine Press, 2007.

3. Hauge OH. Dagbok 1924-1994. Oslo: Det norske samlaget, 2000. 